The pineal region is the most common area for germ cell tumours. They are mostly observed in children. In adults they are more common in men in the second or third decade of life. Pineal tumours have a diverse histopathology. Their growth is slow and the symptoms result from the compression of adjacent cerebral structures. One of the histopathological forms is germinal tumours, including mild or malignant teratoma. They have the ability to release neoplastic markers, e.g. AFP, $\beta$-HCG, which are used to evaluate the effectiveness of surgical and oncological treatment. The paper presents a case of a 24-year-old man diagnosed as teratocarcinoma. The treatment protocol consisted of both surgery and conventional fractionation radiotherapy (Df = $1.8 \mathrm{~Gy}, 5 \times$ weekly) to the total dose of 50.4 Gy. After a few months, there was a recurrence of the cancer process. The patient received 2 courses of chemotherapy, which did not yield the expected therapeutic effect. The patient's prognosis is unfavourable due to rapid local relapse and failure after treatment. The case is presented due to the rarity of pineal teratocarcinoma tumours and the age of the patient.

Key words: pineal germ cell tumours, teratoma, surgical treatment, radiotherapy.

\section{Extragonadal form of germ cell pineal tumour: a case report}

\author{
Malgorzata Chilimoniuk¹, Ewa Olszewska², Aneta Kiluk ${ }^{3}$
}

\author{
${ }^{12}{ }^{\text {nd }}$ Department of Radiotherapy, Marie Sklodowska Curie Oncology Centre \\ in Bialystok, Poland \\ 2Department of Otolaryngology, Medical University of Bialystok, Poland \\ 3 Department of Oncology, Marie Sklodowska Curie Oncology Centre in Bialystok,
} Poland

\section{Introduction}

From the histological perspective, the pineal region is a heterogeneous area which includes the following brain structures: pineal gland, back of the third ventricle and cerebral aqueduct, supraclinoid cavum, brain (the tectum, brain stem, thalamus, splenium of corpus callosum), dura mater and vessels (internal cerebral veins, Galen vein, the inner layer of the choroid, posterior cerebral artery) [1].

Pineal tumours are a rare phenomenon and constitute $0.5-1 \%$ of all intracranial tumours [2]. They can be observed mostly in children; however, in adults, they appear 3-4 times more frequently in men under 30 [3]. Pineal tumours occur in various histological forms.

Beside glandular tissue, they also include glial tissue, endothelial cells and end organs. Therefore, they can be divided according to their origin:

- tissues that dislocated abnormally during embryonic development (GCTs germ cell tumours), i.e. germinoma, embryonal carcinoma, yolk sac tumour, teratoma, choriocarcinoma;

- pineal parenchyma cells (PPts - pineal parenchymal tumours), i.e. pineocytoma, pinealoblastoma;

- cells surrounding parts of the brain, i.e. astrocytoma, glioma, meningioma, ependymoma $[3,4]$.

Clinical symptoms of the pineal tumours generally stem from the compression of the adjacent cerebral structures. They may appear suddenly and progress rapidly. They normally include headaches, nausea, vomiting (typical symptoms of increased intracranial pressure) and hydrocephalus related to the blockage of the cerebrospinal fluid flow through the intracerebral aqueduct. A particularly distinctive symptom resulting from the compression of the corpora quadrigemina is the paralysis of up-gaze, the so-called Parinaud's syndrome. Such ailments as dilation of pupils, anisocoria, strabismus, nystagmus and paresis are a result of prolonged compression of the brain stem and disease development $[1,5,6]$.

\section{Germ cell tumours}

Germ cell tumours (GCTs) constitute approximately $11.85 \%$ of primary intracranial tumours in children and $0.5-3.2 \%$ in adults, where they develop predominantly in the second decade of life. The highest incidence can be observed in Japan [7]. Epidemiological data indicate that morbidity in this country is 0.17 for 100000 people a year, and the dominant sex is male $(9: 1)$ [8]. One of the histopathological forms of this group of tumours is teratoma. They are generally situated in the median plane, most commonly in the gonads as well as in the mediastinum (they constitute about 15\%) [9], the retroperitoneal space, the nervous system (pineal gland) and extremely rarely in the nasopharynx. Teratoma tumours are a result of pathological changes in the embryonic stem 
cell, which is able to differentiate into all derivatives of the three primary germ layers (ectoderm, mesoderm and endoderm). We can distinguish mature teratoma, immature teratomas with malignant transformation and mixed [4]. Most of them are benign; however, cancer may develop as a result of differentiation of one of the tumour tissue elements. Teratomas can be characterized by steady and long growth, although they may reach considerable sizes. They can be cystic or solid (these are less frequent but are usually malignant). They release chorionic gonadotropin ( $\beta$-HCG) or alpha-fetoprotein (AFP). They serve as markers of effectiveness of oncological treatment and recurrence after surgery $[10,11]$. Brain CT scan is an essential diagnostic element. It is a method that determines the tumour size and its topography. The material for histopathological examination can be taken during endoscopy or stereotactic biopsy can be performed.

The aim of this study is to present a young patient with teratocarcinoma with bad prognosis.

\section{Case report}

In October 2009, the patient, aged 24, due to progressing headaches with accompanying nausea and vomiting, was admitted to the Department of Infectious Diseases and Neuroinfection, where meningitis was excluded. The analysis of the cerebrospinal fluid was positive. The patient was taken to the Department of Neurology for further diagnosis. The performed OUN CAT scan (4 November 2009) showed a heterogeneous tumour area with calcinosis of the pineal gland measuring $16 \times 18 \mathrm{~mm}$ modelling the cerebral aqueduct, widened ventricular system with no signs of intracranial bleeding or internal hydrocephalus. The patient was taken to the Department of Neurosurgery, Medical University of Bialystok (MUB), in order to implant a ventriculo-peritoneal shunt (10 November 2009, ventriculostomy of the third ventricle was performed). The surgery and the post-operation period proceeded with no complications. The patient was discharged from the hospital in overall good condition with a recommendation to report at the Department of Neurosurgery in 3 weeks time for surgical treatment of the pineal tumour. At the beginning of December 2009, due to sudden severe headaches with accompanying vomiting, temperature, nystagmus and neck stiffness, the patient was admitted to the Neurology Department in Bialystok. Initial assessment showed that the patient was drowsy, with logical verbal contact. Neurological examination showed neck stiffness, paralysis of the downward and front eyeball movements (eyeballs were directed upward) and horizontal-rotary nystagmus. The CT scan of the brain showed a tumour in the pineal area, modelling the cerebral aqueduct and the third ventricle, with no sign of bleeding, ventricular system not enlarged. Laboratory studies found high concentration of AFP $-309.2 \mathrm{ng} / \mathrm{ml}$ (normal level $-15 \mathrm{ng} / \mathrm{ml}$ ) and B-HCG $-12.7 \mathrm{ng} / \mathrm{ml}$ (normal level $-5 \mathrm{ng} / \mathrm{ml}$ ) in blood serum. Remaining biochemical studies did not deviate from the norm. Applied pharmacological treatment resulted in drop of the fever and vomiting; however, it did not improve the neurological condition of the patient. After examination of the brain, which showed signs of recent bleeding to the tumour, the patient was taken to the De- partment of Neurosurgery for further treatment. In mid December 2009, suboccipital craniotomy and total removal of the brain tumour through supracerebellar access was performed. Due to the length of the operation and respiratory failure, the patient was taken directly from the block to the Intensive Care Department of the MUB. After admission, the patient was in medium-severe condition, unconscious, score 3 on the Glasgow scale, artificially ventilated and circulatory stable. After applied treatment, due to considerable improvement in respiratory efficiency, the patient was disconnected from the ventilator and extubated later in the morning. The patient, in general good condition, with verbal contact, oriented, score 14 on the Glasgow scale, was again taken to the Department of Neurosurgery. A decrease in upward gaze disorder with no neurological deficits was observed. After the operation, control levels of neoplastic marker activity were lowered: AFP $(4.46 \mathrm{ng} / \mathrm{ml})$, B-HCG $(<0.100 \mathrm{ng} / \mathrm{ml})$ and CEA $(1.07 \mathrm{ng} / \mathrm{ml})$. Histopathological examination of the tumour identified teratocarcinoma.

In February 2010, the patient was qualified for additional radiotherapy (brain and spinal cord MRI showed no change in the spinal cord and meninges). Radical radiotherapy with beam energy X $6 \mathrm{MV}$ was commenced, according to an individual treatment plan, in two stages:

I - stage from the opposed lateral fields, fraction dose $1.8 \mathrm{~Gy} /$ ref. p. (referent point) up to a total dose of $30.6 \mathrm{~Gy} / \mathrm{ref}$. p. in 17 fractions. After the dose of $9 \mathrm{~Gy} / \mathrm{ref}$. p., slight esotropia of the left eye was observed, with no sign of nystagmus.

II - stage from the allocated areas, fraction dose $1.8 \mathrm{~Gy} /$ ref. p. up to a total dose of $2.4 \mathrm{~Gy} /$ ref. p. in 13 fractions. Total dose 54 Gy/ref p.

During admission, steroid therapy and proton pump inhibitors were administered. After finishing radiotherapy, another drop in marker levels was achieved - AFP $(1.38 \mathrm{ng} / \mathrm{ml}), \mathrm{B}-\mathrm{HCG}(<0.1000 \mathrm{ng} / \mathrm{ml})$ - and a follow-up MRI of the spinal cord was arranged. After consultation at the Medical Oncology Department, it was determined that the patient did not require additional chemotherapy. Followup MRI of the spinal cord performed 2 months after finishing radiotherapy in June 2010 showed no pathological or focal changes in the C-S region, whereas in the thoracic region the presence of intervertebral disc herniation Th $7 / 8$ with reduction of the reserve capacity of the spinal canal and vertebral body hernias Th8-Th12 were noted. CT OUN scan showed a possibility of metastasis in the tumour bed and a visible focus in the medial area of the cerebellar tentorium. Physical examination showed overall good condition of the patient with no neurological disorders and the level of neoplastic markers at the previous level. The patient remained under supervision.

In August 2010, deterioration of the overall and neurological condition was noted. Hospitalization at the Department of Neurology MUB and CT scan of the brain confirmed metastasis of the pineal tumour (Fig. 1). The patient was not qualified for a neurosurgical procedure, due to the location of the tumour in the deep structures of the brain, which increases the risk of the operation; however, chemotherapy at the Medical Oncology Department of Bialystok Oncology Centre was suggested. Treatment was administered in accordance with the BEK programme (due to the risk of impaction af- 
ter intensive hydration, cisplatin was replaced by carboplatin): Vepesid, Carboplatin, Bleomycin with nausea and vomiting protective drugs and hydration. The first course of chemotherapy was complicated by general weakening and G4 neutropenia. In the follow-up OUN TK, the size of tumours was stabilized, and marker levels were as follows: AFP-78.3 ng/ml, B-HCG- $<0.1 \mathrm{ng} / \mathrm{ml}$. The second course of chemotherapy was administered according to the BEP programme with cisplatin, but it was abandoned after two days due to deterioration of health of the patient and increase of neurological symptoms (positive Parinaud's syndrome, increased deep tendon reflexes in lower limbs with a tendency of positive Babinski syndrome on the left side, left-sided paresis, neck stiffness three fingers width, Kernig's sign apr. 30-40 $)$. The patient's movements were slow; he answered simple questions, and sat on the bed with the help of another person. Dysarthric speech and dysphagia occurred. He was consulted in Lodz, Poland, by a radiotherapist-oncologist to qualify for possible treatment with brain stereotactic techniques after examination excluding neoplasm seeding. The follow-up MRI OUN examination found progress of the cancer process and location of the changes near critical structures. The patient died afterwards.

\section{Discussion}

Prognosis of patients with pineal tumours depends on the level of malignancy, histopathological type and the stage of development $[12,13]$.

In most cases, germ cell tumours have good prognoses, as they present high radiosensitivity and over $90 \%$ of patients live long lives free of disease. The basic method of therapeutic treatment, especially in the case of large tumours, is surgical treatment which relies on the total resection of the changed area. Considering the high sensitivity of dysgerminomas to radiation and chemotherapy, surgical treatment, particularly with small tumours, is rather controversial. Research results have not shown any difference between patients after surgery and additional radiotherapy in comparison to radiotherapy itself [14-17]. Radiotherapy still remains the principal method of treatment of pineal germ cell tumours. In 90\% of cases, it prevents disease recurrence and neoplasm seeding $[15,18]$. There are also contradictory opinions regarding radiation of the whole plane. Metastases to the spinal cord are rare and do not exceed $11 \%$ of all cases. Radiosurgery and fractionated stereotactic radiotherapy are used in treatment of tumours of the central nervous system in surgically unavailable areas. These methods differ in the number of administered doses of radiation in the area of intracerebral pathological change.

In radiosurgery, one high dose of radiation is given, and in fractionated stereotactic radiotherapy several or could be administrated doses. In pineal tumours, in the case of metastasis or non-radical surgical treatment, stereotaxis is used with more than one dose of radiation as a treatment complementing the surgical procedure [19-21]. Chemotherapy is used in cases of disseminated disease or local metastasis as they present high chemosensitivity. The schemes are based on cisplatin or carboplatin, similarly to primary gonad tumour treatment.

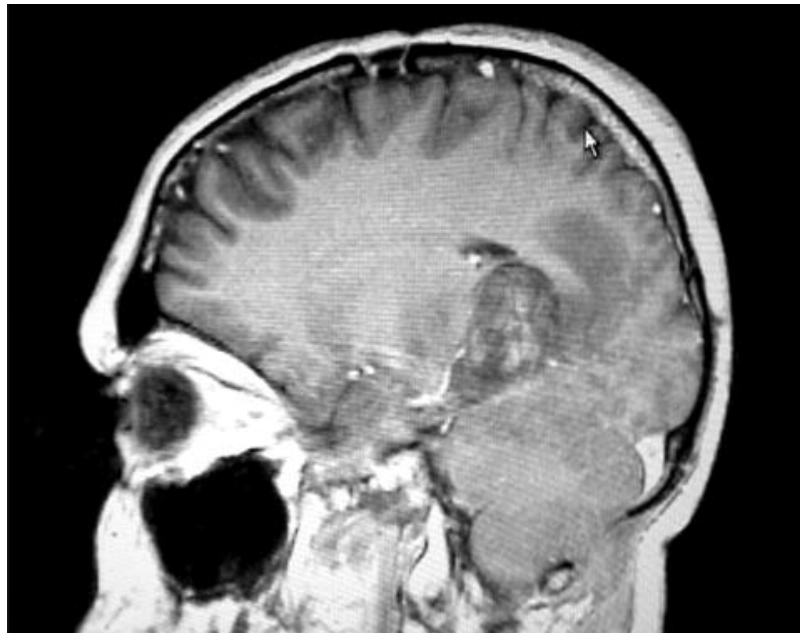

Fig. 1. Postcontrast sagittal MRI image shows large and irregular pineal gland tumour

In the present case, the rather specific symptoms of increased intracranial pressure, Parinaud's syndrome, increased levels of neoplastic markers (AFP, $\beta$-HCG) and characteristic OUN MRI picture indicate the location and the tumour. The prognosis in this case is unfavourable due to fast local metastasis, escalated neurological symptoms and treatment failure.

\section{References}

1. Osborn AG. Pineal region masses. In: Diagnostic Neuroradiology. Mosby, St. Louis, 1994: 408-421.

2. Shapiro WR. Nowotwory ośrodkowego układu nerwowego. Wbeers M (ed.). The Merck mannual. Urban \& Partner, Wrocław 2001; 1707-15.

3. Fevre-Montange M, Vasiljevic A, Champier J, et al. Histopatology of tumors of the pineal region. Future Oncol 2010; 6: 791-809.

4. Hirato J, Nakazato Y. Pathology of pineal region tumors. J Neurooncol 2001; 54: 239-49.

5. Zgliczyński W. Rozpoznawanie i leczenie rzadkich chorób układu podwzgórzowo-przysadkowego. Nowotwory podwzgórza. W: Zgliczyński W (red.). Postępy W rozpoznawaniu i leczeniu chorób podwzgórza i przysadki. Instytut Wydawniczy „Książka i Prasa”, Warszawa 2003; 75-98.

6. Kyung-Sub M, Shin J, Min-Cheol L, et al. Two cases of pineal germinoma with granulomatous inflammation. J Clin Neurosci 2005; 12: 310-3.

7. Committete of Brain Tumor Registry of Japan: The epidemiology and statistic of brain tumors in Japan, 1990 (Japanese).

8. Kuratsu J, Ushio Y. Epidemiologiocal study of primary intracranial tumors: a regional survey in Kumamoto prefecture in the southern part of Japan. J Neurosurg 1996; 84: 946-50.

9. Weidner N. Germ-cell tumors of the mediastinum. Semin Diagn Pathol 1999; 16: 42-50.

10. Karasek M. Guzy szyszynki. W: Pawlikowski M (ed.). Zarys Endokrynologii Klinicznej. Wydawnictwo Lekarskie PZWL, Warszawa 1996; 276-8.

11. Jennings MT, Gelman R, Hochberg F. Intracranial germ - cell tumors: natural history and pathogenesis. J Neurosurg 1985; 63: 155-67.

12. Matsutani M. Guzy szyszynki. W: Ząbek M (ed.). Zarys neurochirurgii. Wydawnictwo Lekarskie PZWL, Warszawa 1999; 145-62.

13. Bruce JN., Balmaceda CM, et al. Guzy okolicy szyszynki. W: Kwieciński H, Kamińska AM (red.). Neurologia Merrita. Urban i Partner, Wrocław 2004; 344-9.

14. Konovalov AN, Pitskhelauri DI. Principles of treatment of the pineal region tumors. Surg Neurol 2003; 59: 250-68. 
15. Tamaki N, Yin D. Therapeutic strategies and surgical results for pineal region tumours. J Clin Neurosci 2000; 7: 125-8.

16. Bruce JN, Stein BM. Infratentorial approach to pineal tumors. W: Neurosurgical procedures: personal approaches to classic operations. Wilson C.B. (ed.). Williams \&Wilkins, Baltimore 1992; 63-76.

17. Bruce JN, Stein BM. Surgical managementof pineal region tumors. Acta Neurochir (Wien) 1995; 134: 130-5.

18. Huh SJ, Shin KH, Ahn YC, et al. Radiotherapy of intracranial germonomas. Radiother Oncol 1996; 38: 19-23.

19. Pollock BE, Carpenter PC. Stereotactic radiosurgery as an alternative to fractionated radiotherapy for patients with recurrent or residual nonfunctionating pituitary adenomas. Neurosurgery 2003; 53: 1086-94.

20. Park P, Chandler WF, Barkan AL, Orrego JJ, et al. The role of radiation therapy after surgical resection of nonfunctional pituitary macroadenomas. Neurosurgery 2004; 55: 100-7.

21. Sheehan JP, Niranjan A, Sheehan JM, Jane JA, et al. Stereotactic radiosurgery for pituitary adenomas: an intermediate review of its safety, efficacy and role in the neurosurgical treatment armamentarium. J Neurosurg 2005; 102: 678-91.

\section{Address for correspondence}

Malgorzata Chilimoniuk

2nd Department of Radiotherapy,

Marie Sklodowska Curie Oncology Centre in Bialystok

Ogrodowa 12

15-047 Bialystok

tel. +48856646720

fax +48 857435913

e-mail: mchilimoniuk@vp.pl 